\title{
THE FORMATION AND DEVELOPMENT OF NEW ZEALAND LEXICOGRAPHY
}

\author{
Anna Bekeeva ${ }^{1 *}$, Elena Notina ${ }^{2}$ \\ ${ }^{1}$ Assoc. Prof., Peoples' Friendship University of Russia - RUDN University, RUSSIA \\ bekeeva_ar@rudn.university \\ ${ }^{2}$ Prof. Dr., Peoples' Friendship University of Russia - RUDN University, RUSSIA \\ notina_ea@rudn.university \\ ${ }^{*}$ Corresponding Author
}

\begin{abstract}
English, the Maori language and New Zealand Sign Language are New Zealand's official languages, with English being the most commonly used. Maori make up approximately 15 percent of the population. New Zealand English is one of the youngest varieties of English and is distinctive in that its full formation and development are documented. An important aspect of the recognition of the existence of a national variety of the English language in New Zealand is the codification of the national norm of the literary language, and primarily through a lexicographic reflection. The paper considers the formation and development of New Zealand lexicography within the framework of the linguistic environment. It has been established that the beginning of the formation of the New Zealand lexicographic practice was connected with the description of the Maori language. It needs to be noted that ethnic, cultural, social and language diversity determined the specifics of New Zealand lexicography. Victoria University has been the main centre for lexicography in New Zealand. A number of outstanding lexicographers include: H. Orsman, T. Deverson, I. Gordon, J. Macalister, G. Kennedy, S. Baker, D. Bardsley, etc. Harry Orsman's New Zealand Dictionary was the culmination of his work as a lexicographer. Harry Orsman's contribution to the codification of New Zealand English is invaluable.It is worth noting that valuable and interesting lexicographic sources allow to research the peculiarities of the New Zealand linguistic reality and to form a reliable idea of the language worldview. The authors conclude the formation of New Zealand lexicography coincided with the origin and development of New Zealand, reflecting the peculiarities of the cultural and linguistic environment in which it was created, as well as the uniqueness of New Zealand English.
\end{abstract}

Keywords: New Zealand, Maori, New Zealand English, variety, lexicography.

\section{INTRODUCTION}

National varieties of a language are formed under the influence of linguistic and extralinguistic factors. The specificity of each national variety is formed under the influence of a special language situation. The method of a comparative analysis of national varieties of the English language with the prestigious British literary norm helps identify differences at all levels of the language structure and allows to understand the national and cultural identity of national varieties. It should be noted that in countries where English has the status of a national variety, the norm acquires its own national characteristics, supported and understood by native speakers. The national variety is one of the fundamental concepts of linguistics in general, there is a rethinking of many problems related to the functioning of language tools in the aspect of a national and cultural specificity of the language.

The main features of the national variety should also include its normalization as a language structure with complex linguistic features, as well as the process of forming its own social models of the language, which resemble the structure of any independent national language. In this paper, we proceed from the fact that the 
specific features of the national variety are most clearly manifested in the features of its norm. National varieties are also checked for the presence of their own codified norm, which is usually presented in the relevant lexicographic reference books (Domashnev, 1990, p. 78).

As a result of the separate use of a language in its territorial, historical and social spaces, it develops characteristic features, according to which the language of the community is differentiated from the language of another national community. When defining the concept of a national variety, it is not enough to state that a language variety has its own characteristics. Just as when determining the essence of a literary language, its normalized nature is noted, national varieties are checked for the presence of their own codified norm.

National normalization of the literary language is one of the most important acts of cultural and linguistic construction of a given nation and finds its lexicographic expression. The processes of national codification of the norms of the literary language take place in line with general norms and do not pursue the goals of linguistic isolation. The national norm, which reflects the essence of the language variety, is sovereign and independent, it is recognized and maintained within each national community (Domashnev, 1989, p.12).

The experimental material for the research of New Zealand scientists was samples of the sounding speech of native English speakers from the sound archive «Mobile Unit». New Zealanders born in 1850 had the same pronunciation characteristics as their parents, that is, early settlers from Great Britain. Early historiographical sources indicate that the New Zealand pronunciation norm was often subjected to harsh and contemptuous criticism. The main lexical and phonetic innovations in New Zealand English emerged on the basis of the dialects of Great Britain and the Maori language. The language or its national variety reflects the activities of the language community in the form of phonetic and lexical units. It is obvious that the New Zealand national literary norm has developed certain features of differentiation from the British English.

\section{METHODOLOGY}

The Lexicography in New Zealand since the early 19th century has reflected important relationships between English and Maori, New Zealand English and Australian English, as well as emergence of distinctive New Zealandisms (Kennedy, 2006, p. 612). The first real attempt to describe the language was produced by Thomas Kendall of the Anglican Church Missionary Society in «A Korau no New Zealand; or, the New Zealander's First Book» published in Sydney in 1815. This 54-page description was a courageous first attempt, but $\mathrm{T}$. Kendall did not have the technical knowledge to adequately describe the language at that time.

Later, however, under the direction of Professor Samuel Lee, an oriental linguist at Cambridge, T. Kendall used his knowledge of Maori, with the assistance of Hongi Hika and Waikato (a Ngapuhi leader), to compile a grammar and vocabulary called «A grammar and vocabulary of the language of New Zealand» in 1820. With information from T. Kendall, Samuel Lee designed an alphabet for Maori based on the Romanic conventions used for Sanskrit. The production of textbooks continues to this day. Hoani Waititi's (1970) two textbooks «Te Rangatahi 1» and «Te Rangatahi 2» were published in the early 1960s. H. Waititi had taught at several secondary schools in the 1950s and recognized the need for a series of resources aimed at second language learners of Maori. They avoided grammatical rules, substituting a sustained use of increasingly complex grammatical constructions. More scholarly and analytic study of the language really dates only from Bruce Biggs' doctoral thesis, which is a strict item and arrangement account of Maori phrase structure.

Other books on the structure and grammar soon followed including Robert Maunsell's, an Irish missionary, «A grammar of the New Zealand language» in 1842, William L. Williams', a missionary and later the first Bishop of Waiapu who studied classics at Oxford, «First lessons in the Maori language with a short vocabulary» in 1862. One of the most important lexicographical projects undertaken shortly after the Treaty of Waitangi was signed by William Williams of the Church Missionary Society was his comprehensive «Dictionary of the New Zealand Language» (1844), the first of seven editions, the last in 1971. This monolingual dictionary excluded transliteration and borrowing from the English language. It should be noted that the Maori script was created on the basis of the Latin alphabet in the XIX century. This historical era is the beginning of lexicographic practice in New Zealand.

Many concepts that exist in one language and culture may be completely absent in another. Recently, there has been a noticeable interest in the compilation of dictionaries. There is a tendency to lexicographic representation of accumulated knowledge and consolidation of the results of research in the form of lexicographic reference books. From the point of view of the theory of intercultural communication, the dictionary is a means of reflecting the culture of a society, its national uniqueness, the peculiarities of its life and activities. 
Important subsequent works on Maori included Biggs B. (1981) "The complete English-Maori dictionary» based on Williams' sixth edition; Ngata, H.M. (1993) «English-Maori dictionary», a comprehensive English dictionary for Maori, reflecting the Maori idiom from the East Coast of the North Island; and Ryan P.M. (1995) "The Reed dictionary of modern Maori», a significant dictionary of English for Maori and English for Maori, containing over 20,000 words from each language; D. Bardsley «The rural New Zealand English lexicon 1842 - 2002» (2003), J. McAllister «The presence of Maori words in New Zealand English» (2003). An English-Maori and Maori-English dictionary of more than 5,000 Maori neologisms was developed by the Maori Language Commission (1996).

Along with English and Maori, New Zealand Sign Language receives strong government support. The language policy implemented in this aspect ensures the observance of tolerance in New Zealand society. On 6 April 2006, New Zealand Sign Language was recognized as the official language of New Zealand. The main purpose of the Act is to encourage and support the use of New Zealand Sign Language. New Zealand sign language has not only similarities with British and Australian sign languages, but also local sign differences. It is believed that New Zealand Sign Language is a variety of the British sign language. The sign language dictionary includes gestures to convey some words from the Maori language.

R. McKee and D. McKee consider that the first NZSL dictionary was produced in 1986 by Dan Levitt, an American interpreter contracted to train the first cohort of sign language interpreters in New Zealand. In the absence of documented NZSL resources, language classes relied upon rosters of Deaf visitors as live language models. During class sessions, their signing was video-recorded and subsequently described and compiled in a dictionary. The next dictionary was a collaborative effort between the national Deaf Association and Victoria University. The project was led by Professor Graeme Kennedy, an editor of the Oxford Dictionary of New Zealand English, who had also supervised a PhD thesis describing the grammar and lexicon of NZSL (Collins-Ahlgren 1989). The 1997 dictionary contains 4,500 entries and was completed in six years. G. Kennedy took a systematic approach to content selection by establishing a taxonomy of semantic domains common to most languages, as well as a list of words (in English and Maori) pertinent to New Zealand life and to Deaf culture (McKee, McKee, 2013, p.503).

Language policy measures extend the rights of the language. Due to government financial support, Kelston Educational Centres in Auckland and Sumner Educational Centres in Christchurch have provided favourable conditions for successful acquisition of the sign language. Research work is carried out on the compilation of teaching aids and dictionaries, educational materials and scientific articles are printed. Interest in the sign language of New Zealand began in the 1990s. Among them are the following works: G. Kennedy, R. Arnold, P. Dugdale, S. Faye, D. Moskowitz «A Dictionary of New Zealand Sign Language» (1997); R. McKee and G. Kennedy «Wellington Dictionary of New Zealand Sign Language» (1999), containing more than 100,000 individual sign designations of English vocabulary; D. Levitt «Introduction to New Zealand Sign Language» (1985); R. McKee and E. D. McKee «Handbook of Grammar of New Zealand Sign Language» (2001); D. Moskowitz «Vocabulary of New Zealand Sign Language» (1996).

One of the most famous dictionaries of sub-standard English vocabulary of the early XX century is «A dictionary of slang and unconventional English» by E. Partridge (1937). The dictionary is equipped with substandard lexical units from the United States, Canada, Australia and New Zealand, as well as dictionary entries from various dictionaries and glossaries. A special interest in slang in New Zealand was shown by the famous scientist S. Baker, who published «A New Zealand slang: a dictionary of colloquialisms» in 1941. S. Baker emphasized the role of Australian English in adding to the lexical composition of New Zealand English: «What would happen in New Zealand if we were suddenly robbed of such serviceable expressions as wowser, larrikin, dinkum, cobber, calling a person hard case, a Pummy or a skite. An argument or fight is a barney, we shout drinks, we occupy a pozzie, we go crook when we are annoyed» (Baker, 1941, p. 62).

\section{RESULTS}

T. Deverson and E. Gordon point out that there is a shift apparent in the way some New Zealanders at least are viewing their own form of English speech. Perhaps the chief factor in this is New Zealand's new, or heightened, sense of independent nationhood. Language is an integral part of any country's cultural makeup. A growth in national maturity and self-respect inevitably brings greater prestige to the national language or variety (Deverson, Gordon, 1998, p. 175). Schneider E. stresses that loosening ties with Britain early in the XX century formalized in the Dominion status in 1907 and full independence in 1947. Linguistically speaking, nativization and indigenization were going on, and a New Zealand accent stabilized. At the same time, the external British language norm remained valid. The effects of the nativization process are most strongly visible on the levels of pronunciation and vocabulary. New Zealand's distinctive lexis includes both further loans from Maori and the subtle creative processes that are typical of this phase: semantic shifts 
(dairy 'corner shop', field 'paddock') new compounds (walkaway, sharemilker), and hybrid compounds (whare boy, manuka blight) (Schneider, 2007, 130-131).

A key aspect of recognizing the sovereignty of a national variety is the codification of its norms in lexicographic sources. The Heinemann New Zealand Dictionary (ed. Harry Orsman) was a landmark publication, the first work to integrate New Zealandisms with the main body of English words to create a general purpose New Zealand dictionary. This was followed by a New Zealand edition of the New Collins Concise English Dictionary, and the Collins New Zealand Compact English Dictionary (by lan Gordon), and by Burchfield's New Zealand Pocket Oxford Dictionary. A further lexicographical landmark was the first substantial publication consisting solely of New Zealand usage, Elizabeth and Harry Orsman's New Zealand Dictionary (1994). It has since been followed by Orsman's major work, the historical Dictionary of New Zealand English (1997). The dictionary will provide an immensely valuable research base for future lexicographers and historians of New Zealand English (Deverson, 1997, p. 43).

\section{CONCLUSION}

We have come to the conclusion that the development of early New Zealand lexicography is primarily associated with the need for communication between English and Maori to establish economic, trade, cultural, and political relations between nations. It has been established that the beginning of the formation of the New Zealand lexicographic tradition was laid by dictionaries, the object of description was Maori. T. Kendall was commissioned by the Church Missionary Society (CMS) to develop an orthography of the Maori language as the first settlers needed to learn to speak Maori. This necessity served as a prerequisite for learning foreign languages, which was not possible without the help of appropriate dictionaries. The peculiarities of the social history of the country and the socio-linguistic situation determined the specifics of the New Zealand lexicography. It should be noted Victoria University has been the main centre for lexicography in New Zealand. A number of outstanding lexicographers include: H. Orsman, T. Deverson, I. Gordon, J. Macalister, G. Kennedy, S. Baker, D. Bardsley, etc. Harry Orsman's New Zealand Dictionary was the culmination of his work as a lexicographer. The dictionary was the result of more than forty years of lexicological work. Harry Orsman's contribution to the codification of New Zealand English is invaluable. Lexicographic theory and practice traditionally rely on the urgent needs of social, industrial, cultural and other spheres of activity, while lexicographic traditions have national specifics. The formation and development of New Zealand lexicography coincided with the origin and development of New Zealand, reflecting the peculiarities of the cultural and linguistic environment in which it was created, as well as the uniqueness of New Zealand English. Maori borrowings distinguish the New Zealand English vocabulary from other varieties.

\section{ACKNOWLEDGEMENTS}

The paper has been supported by the RUDN University Strategic Academic Leadership Program.

\section{REFERENCE LIST}

Baker, S. J. (1941). New Zealand slang: a dictionary of colloquialisms. Christchurch: Whitcombe and Tombs. $114 \mathrm{p}$.

Bardsley, D. F. (2003). The rural New Zealand English lexicon 1842-2002. Ph.D. thesis. Wellington: Victoria University of Wellington.

Biggs, B. (1981). The complete English-Maori dictionary. Auckland: Auckland University Press, 240 p.

Burchfield, R.W. (1972-1986). Supplement to the Oxford English Dictionary. 4 volumes. Oxford: Oxford University Press.

Domashnev, A. I. (1990). Osnovnye osobennosti polinacional'nyh literaturnyh yazykov. Problemy yazykovoj variativnosti [The main features of polynational literary languages. Problems of language variability]. Moscow: Nauka, p. 77-80.

Domashnev, A. I. (1989). Yazykovye otnosheniya v FRG [Language relations in the Federal Republic of Germany]. Leningrad: Nauka, 158 p.

Deverson, T. (1997). New Zealand English. Book \& Print in New Zealand: A Guide to Print Culture in Aotearoa. Wellington: Victoria University Press, p. 40-44. 
Deverson, T., Kennedy, G. D. (2005). The New Zealand Oxford Dictionary. Oxford: Oxford University Press, $1376 \mathrm{p}$.

Gordon, E., Deverson, T. (1998). New Zealand English and English in New Zealand. Auckland: New House Publishers, $208 \mathrm{p}$.

Hay, J., Maclagan, M., \& Gordon, E. (2008). New Zealand English. Edinburg: Edinburg university press, 2008, $184 \mathrm{p}$.

Kennedy, G. (2002). A Concise Dictionary of New Zealand Sign Language. Wellington: Bridget Williams Books, $590 \mathrm{p}$.

Kennedy, G. (2006). New Zealand Lexicography. Encyclopedia of Language \& Linguistics. Second edition. Edited by Brown, K. Elsevier Science, p.612-613.

Lee, S., Kendall, T. (1820). Grammar and vocabulary of the language of New Zealand. London: Church Missionary Society.

Macalister, J. (2003). The presence of Maori words in New Zealand English. Ph.D. thesis. Wellington: Victoria University of Wellington.

Macalister, J. (2005). A Dictionary of Maori Words in New Zealand English. Oxford: Oxford University Press, $216 \mathrm{p}$.

McKee, R., McKee, D. (2013). Making an Online Dictionary of New Zealand Sign Language. Lexikos 23 (AFRILEX-reeks/series 23: 2013), p. 500-531

Maori Language Commission. (1995). Te Matatiki: Contemporary Maori words. Auckland: Oxford University Press, $232 \mathrm{p}$.

Ngata, H.M. (1993). English-Maori dictionary. Wellington: Learning Media, 559 p.

Orsman, H. (1997). The Dictionary of New Zealand English: a dictionary of New Zealandisms on historical principles. Auckland: Oxford University Press, 982 p.

Partridge, E. (1937). A dictionary of slang and unconventional English. London: Routledge.

Ryan, P.M. (1995). The Reed dictionary of Modern Maori. Auckland: Reed Books, 648 p.

Schneider, E. (2007). Postcolonial English: Varieties Around the World. Cambridge University Press, 363 p.

Williams, W. (1844). Dictionary of the New Zealand language. London: Church Missionary Society, 499 p. 